International Journal of English Literature and Social Sciences
Vol-6, Issue-2; Mar-Apr, 2021

\title{
Aphra Behn: The Scarlet Woman
}

\section{(Based on the Third Chapter of Dale Spender's Mothers of the Novel)}

\section{Rokaya Chaarani}

Received: 20 Dec 2020; Received in revised form: 03 Feb 2021; Accepted: 25 Feb 2021; Available online: 07 Mar 2021 (C)2021 The Author(s). Published by AI Publication. This is an open access article under the CC BY license (https://creativecommons.org/licenses/by/4.0/).

\begin{abstract}
Aphra Behn is one of many a woman writer who was both overlooked and discredited by history. Her literary works were prominent back in the late 17th century because they were thought of as "scandalous". Although not much information is known about her real birth name, origins or life story, several intellectuals, especially feminist historians and literary critics, have attempted to shed light on Aphra Behn as a remarkable woman writer and literary figure that slowly but surely marked English literary history long before Jane Austen. For instance, Virginia Woolf exalts her in A Room of One's Own (1929) by saying "All women together ought to let flowers fall upon the tomb of Aphra Behn... for it was she who earned them the right to speak their minds".
\end{abstract}

Keywords-English Literature, Women Writers, Novel, Fiction, Literary Heritage.

\section{INTRODUCTION}

This essay clusters around one of the most highbrow and eloquent female writers of the $17^{\text {th }}$ and $18^{\text {th }}$ century, writers whom Dale Spender revisits in the third chapter of her book Mothers of the Novel (1986). This female writer is Aphra Behn, a writer who is primarily an English dramatist, novelist and poet whose literary productions were and are hitherto both underrepresented and misrepresented in the literary arena. Following this line of thinking, Dale Spender's aim is to unearth both the monumental and the dialectical ramifications of Behn's literary works which were used as a pretext to taint her reputation. As a matter of fact, Aphra Behn's works were both products of and vital contributions to the restoration era in $17^{\text {th }}$ century England, an era where the monarchy witnessed a political, cultural and an artistic revival after years of tragedy and fundamentalism that were caused by civil wars. Like her male counterparts, Aphra Behn enjoyed the wave of freedom of expression that had swept over the literary realm as an upshot of the restoration period's miscellaneous changes. Yet, the very fact that she was a woman, in addition to her immense success and free spirit rendered her in the eyes of male literary critics mysterious and deviated if not promiscuous. As a consequence, Aphra Behn was accused of being indecent and her works were deemed trivial and inauthentic. The blatantly implausible vilification of this English writer is what Dale Spender debunks in her book to offer valuable correctives to Behn's distorted story as well as to unravel some facts about her literary itinerary, a story and facts that were consigned to oblivion by design.

\section{THE LITTLE RAYS OF APHRA BEHN'S BACKGROUND}

Aphra Behn was a traveler and a successful female playwright and novelist, for her works, especially her breakthrough novel Oroonoko (1688), had witnessed a commercial success that raised eyebrows back in $17^{\text {th }}$ century England since she was a woman. Behn is considered as the first professional female writer and poet who earned her living through writing, a sort of writing that proved to be unrivalled at the time by virtue of its uniqueness, wit and flair. In this vein, Behn was known for her ability of switching literary genres seamlessly and brilliantly, for she used to write plays in prose. Furthermore, she was the initiator of the writing of fiction in the literary scene, for she appropriated fiction to craft unconventional narrative techniques that challenge and unsettle misogynistic literary and cultural narratives that devalue and objectify women. Following these lines of thought, Behn's unparalleled writing styles, especially in regards to the art of the novel, made her emerge as one of 
the most innovative and idiosyncraticwriters of the $17^{\text {th }}$ and $18^{\text {th }}$ century, the fact that enabled her to begin a new history (882), in Cixous' terms, in addition to pave the way for other female writers such as Charlotte Bronte and Jane Austen. Notwithstanding, all of her phenomenal achievements were undercut by the men of letters who stigmatized and lampooned her works in the name of indecency. Spender contends that Aphra Behn was publicly attacked and denounced because the focus was primarily directed towards her personal life rather than her literary accomplishments. The latter was, thus, a bridge across which male critics put her as a woman on the ground of the immoral and the obscene. In this respect, Spender states: "I suspect that the charges of 'immorality" are linked with her complete carelessness of convention, her habit of turning the value system upside down, and her irreverence for all things sacred"(58). As noted earlier, the literary mainstream during the restoration period was marked by freedom of expression which was appropriated by everyone who was engaged in the arts. However, because Aphra Behn was not male, her very literary audacity was deemed detrimental.

\section{APHRA BEHN IN THE ENGLISH LITERARY ARENA}

Back then, Aphra Behn intimidated the male literary canon through her special technique of fusing many genres in one story such as romance, tragedy and thriller. Her novel The Nun or the Fair Vow Breaker (1689) epitomizes this line of thinking because it contains an admixture of reality, fantasy, tragedy and romance. Spender explains that Behn's adoption of this unique narrative strategy bestows her plotlines both authenticity and realism, nevertheless, male literary critics disregarded Behn's excellence based on frivolous assessments. According to her, the truth is they could not accept the idea of a female intellectual outwitting the males in terms of literary brilliance, for her works were framed in the romantic fiction genre merely because she incorporates the dimension of love in the storyline. Accordingly, Spender stresses the fact that "Aphra Behn wrote no novel of the 'woman-gets-man' variety. Her characters of both sexes were prone to pursue perilous paths in the name of love, but there was little of the courtly love tradition in their adventures" (58). In fact, the very foundations of the literary arena that was controlled by the men of letters were shaken by Behn's capability of mixing what was thought of as separate literary genres. It is worthwhile to mention that romantic fiction is considered as the written version of gossip which is associated with the female world. Therefore, the men of letters in the $17^{\text {th }}$ century called Behn's novels trivial because they believed that since Aphra Behn is a woman, her narratives cannot be systemic and well- structured, which are the characteristics of literary fiction. Thereby, male literary critics announced that since romantic fiction and gossip are twins and since they insinuate fictitious ingredients, her so-called autobiographical fiction must surely be a myth.

What is known about Aphra Behn is that she traveled to the West Indies where she met new people and explored a different culture. The chronicles acknowledge this fact but they claim that it might be one of the invented stories Behn had recounted about her life. Aphra Behn has long been accused of deception concerning the biographical events that she had integrated in her novels, especially the prominent Oroonoko (1688) where she narrates the adventures of a black prince whom she chose to be the protagonist of the story. In this novel, places such as the West Indies and Surinam represent fundamental parts, for she uses real events that occurred in her travels to render the plotline authentic and realistic. In Oroonoko, Behn mixes imagination and reality, the fact that male literary critics at that time used as an alibi to position her as a deceitful and unscrupulous woman and her works as dishonest. It is notable to state that Spender puts the emphasis on Aphra Behn as being the first novelist who wrote thirteen novels before the novel that is believed to be the first ever to be given birth, which is Robinson Crusoe (1719) by Daniel Defoe. The latter has as well merged fantasy with reality in his novel, a novel that has a venturesome theme just like Oroonoko. Yet, Daniel Defoe was not scathed or shamed for following such a strategy because he was simply a man. In this regard, Spender explains in the following:

Not even Daniel Defoe is now condemned for his lie that Robinson Crusoe is a true account; rather he is condemned for his realistic detail and his construction of authenticity. But when it suits, a woman is dismissed for employing the same skills with good effect: Aphra Behn, who wrote more than thirty years before Ann Radcliffe, and without benefit of models, is systematically and snidely devalued because in the minds of some men it cannot be admitted that she led the life she did (61).

Aphra Behn's novel Oroonoko has another characteristic which is the treatment of critical topical issues such as gender, race, slavery and colonialism, for she deconstructs the complexity of these interrelated themes through the different characters of the story, and especially through the protagonist whom she pictures as a black hero. 


\section{CONCLUSION}

As a deduction, Aphra Behn was a professional female writer of the $17^{\text {th }}$ century whose story was distorted and whose literary contributions were rubbed off of the chronicles. For this reason, Dale Spender has sought to excavate her concealed literary journey so to contend that she, among many other female novelists even before the emergence of Jane Austen, has the prerogative to be part of the collective literary heritage. The latter was and is hitherto defined as belonging to the male, hence, the literary integrity of highbrow women such as Aphra Behn and her sisters were debauched by their male counterparts who felt stultified by virtue of their success. Dale Spender wishes, thus, to put the works of female writers alongside those of their male counterparts even though she is aware of how far-fetched this aim is due to patriarchy's rooted influence. Moreover, Spender insists on the fact that she does not intend in any way to highlight the superiority of then female writers. Her mere goal is to map out, as far as Aphra Behn is concerned, her literary works whose magnificent narrative mechanisms rendered her the most prominent woman of her time, the first woman who began to write in prose. Therefore, her works need to see the light after they were wished away.

\section{REFERENCES}

[1] Cixous, H. (Summer 1976). The Laugh of the Medusa. Signs.1(4), 875- 893. http://www.jstor.org/stable/3173239

[2] Spender, D. (1986). Mothers of the Novel: 100 Good Writers before Jane Austen. Baltimore: Pandora Press.

[3] Woolf, V. (1957 1929). A Room of One's Own. New york; London: Harcourt, Brace, Jovanovich. 